\title{
Thromboendarterectomy for chronic thromboembolic pulmonary hypertension: Insights from histopathological findings of surgical specimens
}

Alexandra E Kovach ${ }^{*}$, Richard N Channick ${ }^{2}$, Gus J Vlahakes ${ }^{3}$, Cameron D Wright ${ }^{3}$, Josanna M Rodriguez-Lopez ${ }^{2}$ and Richard L Kradin $^{1,2}$

${ }^{1}$ Department of Pathology, Massachusetts General Hospital, 55 Fruit Street, Boston, MA, USA

${ }^{2}$ Pulmonary and Critical Care Unit, Massachusetts General Hospital, 55 Fruit Street, Boston, MA, USA

${ }^{3}$ Division of Cardiac and Thoracic Surgery, Massachusetts General Hospital, 55 Fruit Street, Boston, MA, USA

\begin{abstract}
The pathophysiology of chronic thromboembolic pulmonary hypertension is uncertain. Although thromboendarterectomy has become a common treatment modality, few reports have examined characteristics of surgical thromboendarterectomy specimens with respect to pre-endarterectomy pulmonary artery pressures. We hypothesized that comprehensive clinicopathologic review of specimens at our chronic thromboembolic pulmonary hypertension surgical referral center may provide pathophysiologic insight into this disorder. We reviewed clinical and histopathologic features of patients who underwent pulmonary thromboendarterectomy for chronic thromboembolic pulmonary hypertension at the Massachusetts General Hospital from 2010-2013. A panel of histochemical and immunohistochemical stains was applied. We examined the thromboendarterectomy specimens of 22 women and 20 men (mean age 55 years, range $30-78$ ) who had pulmonary arterial pressures determined by right heart catheterization. 19 patients (45\%) had a documented history of deep venous thrombosis. Other comorbid conditions included autoimmune diseases and various cardiopulmonary disorders. Histological examination revealed variably organized pulmonary thrombi, neovascularization, intimal hyperplasia with associated elastic reduplication, medial calcification and increased medial smooth muscle. Thromboendarterectomy specimens that included diffusely organized thrombi were larger than those with acute thrombus or focal organization $(\mathrm{p}=0.016)$. Atheromatous change was associated with higher pre-operative mean pulmonary arterial pressures $(53$ vs. $45 \mathrm{~mm} \mathrm{Hg}, \mathrm{p}=0.04)$. These results suggest that vascular remodeling may be a critical hemodynamic factor in chronic thromboembolic pulmonary hypertension.
\end{abstract}

\section{Introduction}

Chronic thromboembolic disease is a recognized cause of pulmonary hypertension (chronic thromboembolic pulmonary hypertension) [1,2]. Following a pulmonary thromboembolic event, chronic thromboembolic pulmonary hypertension develops in 1-3.8\% of adults at 2 years following the initial event $[3,4]$. However, the true incidence of chronic thromboembolic pulmonary hypertension is likely higher, as many thrombotic events go unrecognized, and mild degrees of pulmonary arterial hypertension may be asymptomatic.

The precise pathophysiology of chronic thromboembolic pulmonary hypertension is unknown [5], and descriptions of the histologic features are few [6,7]. Pulmonary thromboendarterectomy, is the current treatment of choice for patients with surgically accessible and amenable disease [8]. Endarterectomy has been shown to improve patient hemodynamics and exercise capacity in large-scale comparisons with non-operative, medication-based management strategies [9], and a number of centers have published markedly improved clinical outcomes following surgical endarterectomy [10,11]. In 2010, the Massachusetts General Hospital began a referral-based surgical endarterectomy program for chronic thromboembolic pulmonary hypertension.

We hypothesized that a comprehensive clinicopathologic evaluation of patients with chronic thromboembolic pulmonary hypertension and thromboendarterectomy specimens would shed light on the pathogenesis and management of chronic thromboembolic pulmonary hypertension. We report our findings from these analyses, which support the prevailing hypothesis that vascular remodeling, likely including in situ thrombosis, may be a critical hemodynamic factor in chronic thromboembolic pulmonary hypertension

\section{Material and methods}

We reviewed clinical and pathologic features of patients who underwent pulmonary thromboendarterectomy for chronic thromboembolic pulmonary hypertension at Massachusetts General Hospital from 2010-2013. Institutional Review Board approval was obtained for waived-consent review of archival pathologic materials and associated clinical records. A database of consecutive pulmonary endarterectomy procedures performed from 2010-2013 was obtained from the Department of Cardiac Surgery. Demographic, clinical, and pulmonary hemodynamic information on each associated patient was gathered.

Correspondence to: Alexandra E. Kovach, Department of Pathology, Microbiology and Immunology, Vanderbilt University School of Medicine, 11236 Doctors' Office Tower, Box 3-9065, 2200 Children's Way, Nashville, TN 37232-9065, Tel: 615-936-2879; Fax: 615-936-7828; E-mail: alexandra.kovach@vanderbilt.edu

Key words: chronic thromboembolic disease, pulmonary hypertension, pulmonary pathology

Received: March 10, 2017; Accepted: April 21, 2017; Published: April 24, 2017 
Archived hematoxylin-and-eosin-stained sections, prepared from formalin-fixed paraffin-embedded tissue following each endarterectomy, were reviewed (one per case prepared at the time of clinical processing). On selected cases (8 cases) as part of this study, a panel of immunohistochemical and special stains was applied to the sections to help illustrate the composition of thrombi and their relationship to the vascular wall. Stains included Miller's elastic, Masson's trichrome, factor XIII, smooth muscle actin, CD31, and tryptase (Leica BOND, Leica Biosystems, Buffalo Grove, IL).

Clinical parameters were compared with histologic findings. Statistical analysis was performed using GraphPad QuickCalcs software (GraphPad Software, Inc., La Jolla, CA). Fisher's exact test was used on each comparison of proportions, Student's t test was used for comparison of means between groups, and $\mathrm{R}^{2}$ test was used for comparison of proportions on paired samples. All $\mathrm{p}$ values were two-tailed and were considered statistically significant at a level of less than 0.05 .

\section{Results}

\section{Patient population}

42 patients underwent pulmonary endarterectomy at the Massachusetts General Hospital from 2010-2013 (Table 1). Patients

Table 1. Comorbid conditions in patients with chronic thromboembolic pulmonary hypertension (CTEPH) who underwent pulmonary thromboendarterectomy (PTE).

\begin{tabular}{|c|c|c|c|c|c|c|c|c|c|c|c|c|c|}
\hline \multirow[b]{2}{*}{ Patient } & \multirow[b]{2}{*}{$\begin{array}{c}\text { Age at } \\
\text { Surgery } \\
\text { (years) }\end{array}$} & \multirow[b]{2}{*}{ Gender } & \multirow[b]{2}{*}{$\begin{array}{c}\text { mPAP } \\
(\mathrm{mmHg})\end{array}$} & \multirow[b]{2}{*}{$\begin{array}{l}\text { History } \\
\text { of DVT }\end{array}$} & \multirow[b]{2}{*}{$\begin{array}{c}\text { Obesity } \\
(\text { BMI }>30)\end{array}$} & \multirow[b]{2}{*}{$\begin{array}{c}\text { Add'l } \\
\text { Comorbidity }\end{array}$} & \multirow[b]{2}{*}{$\begin{array}{c}\text { Smoking } \\
\text { Status }\end{array}$} & \multicolumn{3}{|c|}{ Specimen 1 (Right PA) } & \multicolumn{3}{|c|}{ Specimen 2 (Left PA) } \\
\hline & & & & & & & & $\begin{array}{l}\text { Thrombus } \\
\text { Acute } \\
\text { component }\end{array}$ & Recanalization & $\begin{array}{c}\text { Atheromatous } \\
\text { change }\end{array}$ & $\begin{array}{c}\text { Thrombus } \\
\text { Acute } \\
\text { Component }\end{array}$ & Recanalization & $\begin{array}{c}\text { Athero } \\
\text { matos } \\
\text { change }\end{array}$ \\
\hline 1 & 42 & $\mathrm{~F}$ & 20 & No & No & & Never & $\mathrm{N}$ & $\mathrm{Y}$ & $\mathrm{N}$ & $\mathrm{N}$ & $\mathrm{Y}$ & $\mathrm{N}$ \\
\hline 2 & 64 & $\mathrm{~F}$ & 22 & No & No & & Never & $\mathrm{Y}$ & $\mathrm{Y}$ & $\mathrm{N}$ & $\mathrm{Y}$ & $\mathrm{N}$ & $\mathrm{N}$ \\
\hline 3 & 46 & M & 26 & Yes & Yes & & & $\mathrm{N}$ & $\mathrm{Y}$ & $\mathrm{N}$ & $\mathrm{N}$ & $\mathrm{Y}$ & $\mathrm{N}$ \\
\hline 4 & 45 & $\mathrm{~F}$ & 27 & Yes & Yes & RA & Current & $\mathrm{Y}$ & $\mathrm{N}$ & $\mathrm{N}$ & $\mathrm{Y}$ & $\mathrm{N}$ & $\mathrm{N}$ \\
\hline 5 & 77 & M & 29 & Yes & No & CAD & Never & $\mathrm{Y}$ & $\mathrm{N}$ & $\mathrm{N}$ & $\mathrm{Y}$ & $\mathrm{N}$ & $\mathrm{N}$ \\
\hline 6 & 74 & M & 30 & Yes & No & & Never & $\mathrm{Y}$ & $\mathrm{N}$ & $\mathrm{N}$ & $\mathrm{Y}$ & $\mathrm{N}$ & $\mathrm{N}$ \\
\hline 7 & 76 & M & 32 & Yes & No & & Former & $\mathrm{N}$ & $\mathrm{Y}$ & $\mathrm{N}$ & $\mathrm{N}$ & Y & $\mathrm{N}$ \\
\hline 8 & 76 & $\mathrm{~F}$ & 33 & No & Yes & & Never & $\mathrm{Y}$ & $\mathrm{Y}$ & $\mathrm{N}$ & & & \\
\hline 9 & 50 & $\mathrm{M}$ & 34 & No & No & & Former & $\mathrm{Y}$ & $\mathrm{N}$ & $\mathrm{N}$ & $\mathrm{Y}$ & $\mathrm{N}$ & $\mathrm{N}$ \\
\hline 10 & 67 & M & 34 & No & No & & Never & Y & $\mathrm{N}$ & $\mathrm{N}$ & $\mathrm{Y}$ & $\mathrm{N}$ & $\mathrm{N}$ \\
\hline 11 & 45 & $\mathrm{M}$ & 40 & No & No & VSD & & $\mathrm{N}$ & $\mathrm{N}$ & $\mathrm{N}$ & $\mathrm{N}$ & $\mathrm{N}$ & $\mathrm{N}$ \\
\hline 12 & 56 & $\mathrm{~F}$ & 40 & Yes & Yes & COPD & Current & $\mathrm{N}$ & $\mathrm{N}$ & $\mathrm{N}$ & $\mathrm{N}$ & $\mathrm{N}$ & $\mathrm{N}$ \\
\hline 13 & 34 & $\mathrm{~F}$ & 42 & Yes & Yes & APLAS & & $\mathrm{Y}$ & $\mathrm{N}$ & $\mathrm{N}$ & $\mathrm{Y}$ & $\mathrm{N}$ & $\mathrm{N}$ \\
\hline 14 & 67 & $\mathrm{M}$ & 42 & Yes & No & & & $\mathrm{N}$ & $\mathrm{N}$ & $\mathrm{Y}$ & $\mathrm{N}$ & $\mathrm{N}$ & $\mathrm{Y}$ \\
\hline 15 & 77 & M & 43 & No & No & COPD & Former & $\mathrm{Y}$ & $\mathrm{N}$ & $\mathrm{N}$ & $\mathrm{Y}$ & $\mathrm{N}$ & $\mathrm{N}$ \\
\hline 16 & 56 & $\mathrm{M}$ & 45 & No & Yes & & Never & $\mathrm{N}$ & $\mathrm{N}$ & $\mathrm{N}$ & $\mathrm{N}$ & $\mathrm{N}$ & $\mathrm{N}$ \\
\hline 17 & 34 & $\mathrm{~F}$ & 47 & No & Yes & & Never & $\mathrm{Y}$ & $\mathrm{Y}$ & $\mathrm{N}$ & $\mathrm{Y}$ & $\mathrm{Y}$ & $\mathrm{N}$ \\
\hline 18 & 49 & $\mathrm{~F}$ & 47 & No & Yes & APLAS & & $\mathrm{Y}$ & $\mathrm{N}$ & $\mathrm{N}$ & $\mathrm{Y}$ & $\mathrm{N}$ & $\mathrm{N}$ \\
\hline 19 & 71 & $\mathrm{~F}$ & 48 & No & Yes & & Never & Y & $\mathrm{N}$ & $\mathrm{N}$ & $\mathrm{N}$ & Y & $\mathrm{N}$ \\
\hline 20 & 75 & $\mathrm{~F}$ & 48 & Yes & No & & Never & $\mathrm{Y}$ & $\mathrm{N}$ & $\mathrm{N}$ & $\mathrm{N}$ & $\mathrm{N}$ & $\mathrm{N}$ \\
\hline 21 & 78 & $\mathrm{M}$ & 48 & No & No & & Former & $\mathrm{Y}$ & $\mathrm{N}$ & $\mathrm{N}$ & $\mathrm{N}$ & $\mathrm{N}$ & $\mathrm{N}$ \\
\hline 22 & 54 & $\mathrm{~F}$ & 49 & No & No & COPD & Former & $\mathrm{Y}$ & $\mathrm{Y}$ & $\mathrm{N}$ & $\mathrm{Y}$ & $\mathrm{Y}$ & $\mathrm{N}$ \\
\hline 23 & 58 & M & 49 & No & No & & Never & $\mathrm{N}$ & $\mathrm{Y}$ & Y & $\mathrm{N}$ & $\mathrm{N}$ & $\mathrm{N}$ \\
\hline 24 & 40 & $\mathrm{~F}$ & 50 & Yes & Yes & APLAS & Never & Y & $\mathrm{N}$ & $\mathrm{N}$ & $\mathrm{N}$ & $\mathrm{Y}$ & $\mathrm{N}$ \\
\hline 25 & 60 & M & 50 & No & No & & Never & $\mathrm{Y}$ & $\mathrm{N}$ & $\mathrm{N}$ & $\mathrm{N}$ & $\mathrm{N}$ & $\mathrm{N}$ \\
\hline 26 & 31 & $\mathrm{~F}$ & 51 & No & Yes & & Never & $\mathrm{N}$ & $\mathrm{Y}$ & $\mathrm{N}$ & $\mathrm{N}$ & Y & $\mathrm{N}$ \\
\hline 27 & 72 & $\mathrm{M}$ & 51 & Yes & Yes & & Never & $\mathrm{Y}$ & $\mathrm{N}$ & $\mathrm{Y}$ & $\mathrm{Y}$ & $\mathrm{N}$ & $\mathrm{Y}$ \\
\hline 28 & 74 & $\mathrm{~F}$ & 51 & No & Yes & & & $\mathrm{Y}$ & $\mathrm{N}$ & Y & $\mathrm{N}$ & $\mathrm{Y}$ & $\mathrm{N}$ \\
\hline 29 & 38 & $\mathrm{~F}$ & 52 & No & Yes & & & $\mathrm{N}$ & $\mathrm{N}$ & $\mathrm{N}$ & $\mathrm{Y}$ & $\mathrm{N}$ & $\mathrm{N}$ \\
\hline 30 & 59 & $\mathrm{M}$ & 52 & Yes & Yes & & Current & $\mathrm{Y}$ & $\mathrm{N}$ & $\mathrm{N}$ & $\mathrm{Y}$ & $\mathrm{N}$ & $\mathrm{N}$ \\
\hline 31 & 43 & $\mathrm{M}$ & 53 & No & Yes & & Former & $\mathrm{N}$ & $\mathrm{N}$ & $\mathrm{Y}$ & $\mathrm{Y}$ & $\mathrm{N}$ & $\mathrm{N}$ \\
\hline 32 & 49 & M & 53 & No & No & & Former & $\mathrm{N}$ & $\mathrm{Y}$ & $\mathrm{N}$ & $\mathrm{N}$ & $\mathrm{Y}$ & $\mathrm{N}$ \\
\hline 33 & 62 & $\mathrm{M}$ & 54 & Yes & yes & $\mathrm{CA}$ & Former & $\mathrm{Y}$ & $\mathrm{N}$ & $\mathrm{N}$ & $\mathrm{N}$ & $\mathrm{N}$ & $\mathrm{N}$ \\
\hline 34 & 56 & $\mathrm{M}$ & 57 & No & No & CA, ESRD & & $\mathrm{Y}$ & $\mathrm{N}$ & $\mathrm{N}$ & $\mathrm{Y}$ & $\mathrm{N}$ & $\mathrm{N}$ \\
\hline 35 & 30 & $\mathrm{~F}$ & 58 & Yes & No & & Former & $\mathrm{Y}$ & $\mathrm{N}$ & $\mathrm{N}$ & $\mathrm{Y}$ & $\mathrm{N}$ & $\mathrm{Y}$ \\
\hline 36 & 53 & $\mathrm{~F}$ & 58 & No & No & UC & Never & $\mathrm{N}$ & $\mathrm{N}$ & $\mathrm{N}$ & $\mathrm{N}$ & $\mathrm{N}$ & $\mathrm{N}$ \\
\hline 37 & 63 & $\mathrm{~F}$ & 59 & No & Yes & & Former & $\mathrm{N}$ & $\mathrm{Y}$ & $\mathrm{N}$ & $\mathrm{N}$ & $\mathrm{Y}$ & $\mathrm{N}$ \\
\hline 38 & 52 & $\mathrm{~F}$ & 60 & No & Yes & APLAS & Former & $\mathrm{Y}$ & $\mathrm{Y}$ & $\mathrm{N}$ & $\mathrm{Y}$ & $\mathrm{Y}$ & $\mathrm{N}$ \\
\hline 39 & 34 & $\mathrm{~F}$ & 64 & No & Yes & ITP & & $\mathrm{N}$ & $\mathrm{N}$ & $\mathrm{Y}$ & $\mathrm{N}$ & $\mathrm{N}$ & $\mathrm{Y}$ \\
\hline 40 & 50 & $\mathrm{~F}$ & 70 & No & No & COPD & & $\mathrm{N}$ & $\mathrm{Y}$ & $\mathrm{N}$ & $\mathrm{N}$ & $\mathrm{Y}$ & $\mathrm{N}$ \\
\hline 41 & 39 & $\mathrm{~F}$ & unknown & Yes & No & PCD & Never & $\mathrm{N}$ & $\mathrm{N}$ & $\mathrm{N}$ & $\mathrm{N}$ & $\mathrm{N}$ & $\mathrm{N}$ \\
\hline 42 & 52 & $\mathrm{M}$ & unknown & No & No & & Former & $\mathrm{Y}$ & $\mathrm{N}$ & $\mathrm{N}$ & $\mathrm{N}$ & $\mathrm{N}$ & $\mathrm{Y}$ \\
\hline
\end{tabular}

In a cohort of 42 patients, $10(24 \%)$ were identified as having significant comorbid conditions. Underlying cardiac and pulmonary conditions included severe chronic obstructive pulmonary disease (COPD, 2 patients) and repaired ventricular septal defect (VSD, 1 patient), respectively. Underlying pro-coagulation predisposition, in addition to 19 patients who had a history of documented deep venous thrombosis, included 2 patients with antiphospholipid antibody syndrome (APLAS) and 1 patient with hereditary protein C deficiency. Separately, 20 patients $(48 \%)$ were considered obese pre-operatively, and $16(38 \%)$ were current or former cigarette smokers. 
included 22 women and 20 men, with a mean age of 55 years (range 30-78 years, SD 14.5 years). 19 patients (45\%) had a documented history of deep venous thrombosis in either the lower (18) or upper (1) extremities with no predisposing comorbidity. Approximately half of patients $(20 / 42,48 \%)$ were obese, defined as a body mass index of $\geq 30$, and 16 patients (38\%) were current (4) or former (12) cigarette smokers. Other documented co-morbid conditions were identified in 12 patients (29\%). Three patients had antiphospholipid antibody syndrome, two had severe chronic obstructive pulmonary disease, two had rheumatoid arthritis, and one patient each had dialysis-dependent end-stage renal disease, ulcerative colitis, idiopathic thrombocytopenic purpura, coronary artery disease status-post bypass grafting, and a remote history of ventricular septal defect status-post repair. One patient each with antiphospholipid antibody syndrome, chronic obstructive pulmonary disease, and rheumatoid arthritis and the patients with ulcerative colitis and coronary artery disease had a prior confirmed deep venous thrombosis. No patient had dysfibrinogenemia or another coagulopathy.

Pre-operative mean pulmonary arterial pressures were measured in $40 / 42$ patients prior to surgery at a median of 93 days. The resting mean pulmonary arterial pressures values ranged from $20-70 \mathrm{mmHg}$ (mean $45 \mathrm{mmHg}$, median $48 \mathrm{mmHg}$, standard deviation $11.7 \mathrm{mmHg}$, normal reference range $9-18 \mathrm{mmHg}$ ). There was no significant difference in mean pulmonary arterial pressures based on gender $(\mathrm{p}=0.085)$, history of confirmed DVT $(\mathrm{p}=0.25)$, obesity $(\mathrm{p}=0.25)$, or other comorbid condition $(\mathrm{p}=0.60)$.

\section{Histopathologic findings and clinical correlations}

$41 / 42$ (98\%) of patients underwent bilateral pulmonary endarterectomy procedures so that two specimens (left and right pulmonary thromboendarterectomy specimens) were examined for all but one patient. Of the 83 pulmonary thromboendarterectomy specimens, the size of the pulmonary thromboendarterectomy specimens ranged from 1.9 to $9.0 \mathrm{~cm}$ (mean $4.4 \mathrm{~cm}+/-1.5 \mathrm{~cm}$ ). Smaller specimen size was associated with female gender $(\mathrm{p}=0.03)$ but not with laterality $(\mathrm{p}=0.080)$. The size of the pulmonary thromboendarterectomy specimen did not correlate with pre-operative mean pulmonary arterial pressures or patient age. There was no correlation between the size of paired specimens (left and right pulmonary thromboendarterectomy material) from a given patient.

Specimens were variably fragmented post-operatively but recapitulated the shape of the branching pulmonary arterial lumens and included the adherent white-tan intimal wall. Arterial thrombi were deep brown with grossly visible laminations.

Histologically, the luminal fibrin thrombi showed variable degrees of organization. Approximately half $(n=40,48 \%)$ showed welldeveloped organization of the thrombus as evidenced by compression of fibrin, loose fibroblast proliferation, in-growth of endothelial cells and/or collagenous intimal fibrosis with recanalization (Figure 1A). The remainder of the specimens $(n=43$, or $52 \%)$ showed acute thrombus formation with minimal organization (1B). In several cases, unorganized fibrin was seen in close associated with vascular intima (1C). Specimens with diffusely well-organized thrombi were larger than those with acute thrombus or early organization only $(\mathrm{p}=0.016)$.

Heterogeneity in thrombus organization was also seen across the material from a given patient; for 10 of 41 patients with bilateral procedures (24\%), left and right pulmonary thromboendarterectomy specimens showed different degrees of organization, with one side

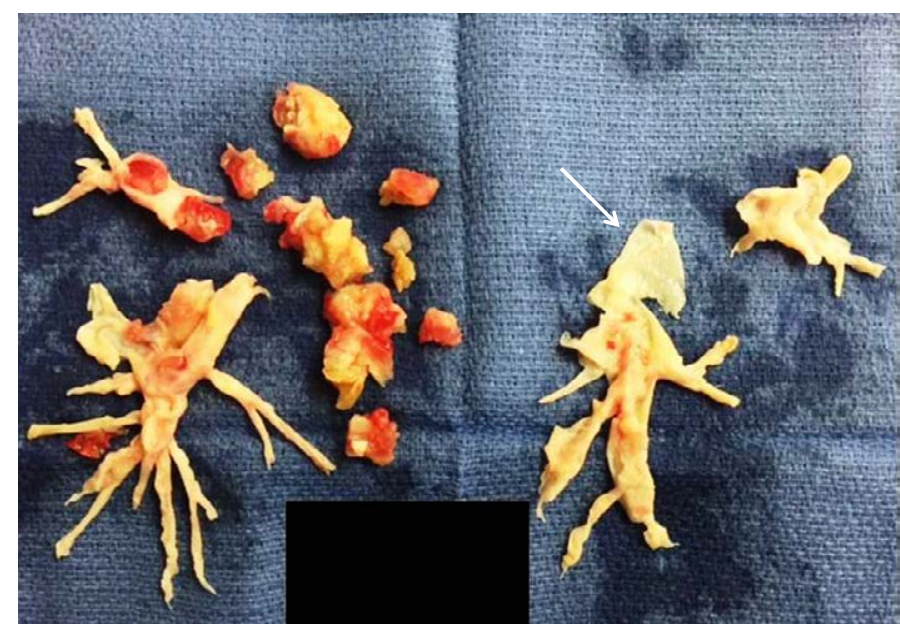

Figure 1. Thromboendarterectomy specimen submitted to pathology

Arrow: adherent vascular wall

showing foci of recent activity (acute thrombus or early organization) and the other showing more uniform organization. Curiously, in 8/ 10 PTE showing differences in degree of thrombus organization, the recent thrombus was seen on the right.

Evidence of recanalization of thrombi was observed in $26 / 83$ pulmonary thromboendarterectomy specimens (31\%); the vascular endothelial lining of neovascular channels was highlighted by immunohistochemical stains for CD31 (Figure 1D). Interestingly, $8 / 43$ specimens with uniformly well-organized thrombi showed recanalization compared with $18 / 40(45 \%)$ specimens with focal areas of acute thrombus or early organization $(\mathrm{p}=0.017)$.

Atheromatous changes, characterized histologically by the presence of foamy lipid-laden macrophages, cholesterol clefts, and chronic inflammation, were present in $11 / 83$ specimens (13\%). The presence of atheromatous changes was associated with higher pre-operative mean pulmonary arterial pressures (mean $52.5 \mathrm{mmHg}$, SD $7.7 \mathrm{mmHg}$ ) compared to the mean pulmonary arterial pressures in cases where atheromatous changes were not observed (mean $44.6 \mathrm{mmHg}$, SD 11.8 $\mathrm{mmHg})(\mathrm{p}=0.044)$. There was no statistically significant difference in the frequency of atheromatous changes seen in specimens with uniformly organized thrombus $(7 / 43,16 \%)$ compared with those with a degree of acute or newly organized thrombus $(4 / 40,10 \%)(\mathrm{p}=0.53)$.

Adherent strips of vessel wall, when present, showed consistent pathologic changes of various severities. The vascular media was variably thickened by dense collagenous tissue. Foci of dystrophic calcification were present in the media of $31 / 83$ specimens (37\%) (Figure 2A, bottom left). Intimal hyperplasia was variable. Histologically, intimal hyperplasia (Figure 2A inset) showed a proliferation of fibroblasts, frequently with associated myxoid stroma, scattered lymphocytes and plasma cells, and rare mast cells, identified by immunohistochemical evidence of tryptase expression (Figure 2B). The endothelial cell lining was largely denuded, or difficult to visualize due to thrombus tightly adherent to vascular wall.

Intimal hyperplasia was associated with reduplication of the internal elastic lamina, highlighted by Miller's elastic stain (Figure 1C). Additional elements in the intima and extending into the media in areas included vascular smooth muscle, highlighted in a subset of cases by smooth muscle actin (Figure 1D). The role of macrophages in crosslinking fibrin in the vascular wall was highlighted by the increased 


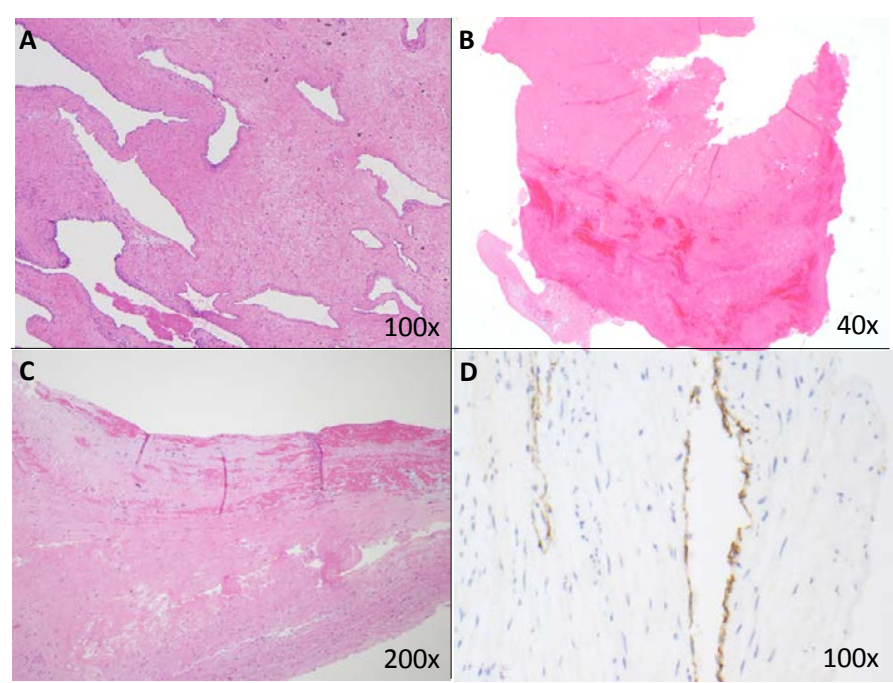

Figure 2. Thrombi from endarterectomy specimens: representative histopathology 1A: This specimen, from a 64-year-old man with a pre-operative mean pulmonary arterial pressure (mPAP) of $54 \mathrm{mmHg}$, shows a remote, organized thrombus with dense sclerotic collagen and recanalization with vascular channels (100x magnification).

1B: More than half of specimens $(n=43,52 \%)$ showed acute thrombus with early organization, without fibroblastic in-growth or inflammation (40x). In the lower left corner of this image, a small portion of vascular intima is attached to a thrombus showing early organization.

1C: Several specimens showed fresh fibrin adherent to vascular intima (top half of figure, 200x).

1D: Recanalization/neovascularization of thrombi was identified in approximately onethird of cases. The vascular endothelial lining of the neovascular channels is highlighted by an immunohistochemical stain for CD31 (100x).
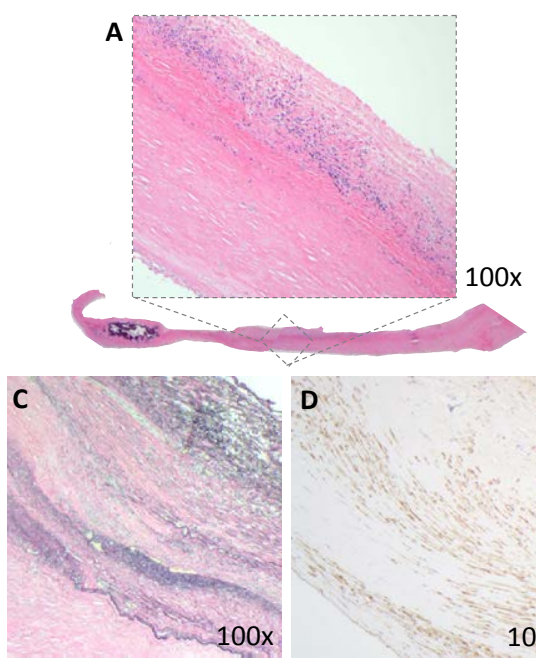

\begin{abstract}
D
\end{abstract}

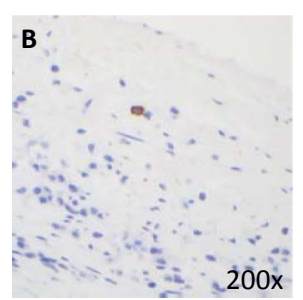

E
Figure 3. Adherent vascular wall from endarterectomy specimens: representative histopathology

1A: Vascular media was variably thickened by dense collagenous tissue (bottom) and focal calcification (lower left) (20x). Intimal hyperplasia (inset, 100x) was composed of a proliferation of fibroblasts, myxoid stroma, scattered lymphocytes and plasma cells.

1B: Rare tryptase-positive mast cells were scattered within the intimal proliferation (200x) 1C: Intimal hyperplasia was associated with reduplication of internal elastic lamina (elastic stain, 100x).

1D: Increased vascular smooth muscle was seen in the intima and media (immunohistochemical stain against smooth muscle actin, or SMA; 100x).

1E: Immunohistochemical stain shows Factor XIII+ macrophages within the vascular intima (100x).

presence of factor XIIIa macrophages in areas of intimal remodeling (Figure 1E).

\section{Discussion}

The results of our clinicopathologic review of endarterectomy specimens from a large surgical center support the prevailing hypothesis that in situ thrombosis and remodeling of pulmonary vasculature is a hemodynamic factor in chronic thromboembolic pulmonary hypertension.

A number of recent translational studies have supported the hypothesis that chronic thromboembolic pulmonary hypertension is partially a consequence of interaction with the local pulmonary artery, rather than simply a result of repeated thromboembolic events. Ex vivo culture experiments have shown unique metabolic and other functional activities of pulmonary arterial endothelium [12,13], fibroblastic/myofibroblastic populations [14,15], and vascular smooth muscle [16,17], suggesting functional interactions between the vascular wall and luminal thrombi [18].

In our series, greater than half of patients $(23 / 42$ (55\%) did not have a confirmed history of thromboembolic disease or associated deep venous thrombosis. Only a small subset had pulmonary, rheumatologic, or hematologic/coagulative comorbidities. Moreover, approximately half $(52 \%)$ of pulmonary thromboendarterectomy specimens lacked the histological features of thromboemboli and instead showed acute thrombus formation with early organization $(\mathrm{p}=0.016)$. This finding suggests active, ongoing situ thrombus formation on a previously damaged endothelial surface. Indeed, prior descriptive reports of surgical pathology thromboendarterectomy specimens also showed variable clot organization [6,7].

The increased thrombus formation within pulmonary arteries on the right, seen in our series as well as prior published reports [6,7], bears elaboration. The right pulmonary artery has a more distal initial branch point and carries a relatively higher blood volume than the left pulmonary artery [19], factors that may contribute to greater intraluminal turbulence. These findings support an important contribution by thrombosis in situ in chronic thromboembolic pulmonary hypertension, commensurate with evidence in the literature [20-26].

The dominant histologic finding in the pulmonary vascular wall was intimal hyperplasia. This was variable across specimens and characterized by fibromyxoid proliferation with mild chronic inflammation. We hypothesize that macrophages expressing cell surface factor XIIIa may play a role in the cross-linking of the fibrin clot to matrix fibronectin and collagen [27]. Other pathologic features of the vascular wall included dense collagen and focal dystrophic calcification in the medial layer. One prior published histologic study of affected pulmonary veins adopted morphometric techniques to map the distribution of intimal lesions along the course of diseased arteries [20]. The authors found that intimal hyperplasia was well developed in larger branches of the pulmonary artery in cases of chronic thromboembolic pulmonary hypertension and not in cases of pulmonary hypertension of other causes, including idiopathic cases where the intimal hyperplasia was seen best in distal small arteries and arterioles. This finding suggests unique pathogenic mechanisms in the disparate causes of pulmonary hypertension.

Atheromatous change, observed in a minority of the endarterectomy specimens in our series (13\%), appeared to be an indicator of severity of pre-operative mean pulmonary arterial pressures $(\mathrm{p}=0.044)$. While derived from a small sample size, this result is in keeping with the classic model of atheroma formation with endothelial disruption due 
to elevated intravascular pressures or other flow-related barotraumas [19]. Pre-operative mean pulmonary arterial pressures did not correlate with other histopathologic features, including specimen size or degree of thrombus organization.

Pulmonary hypertension may also occur as a primary idiopathic condition, some cases of which have been identified as manifestations of genetic predisposition [22]. Study of the natural history of chronic thromboembolic pulmonary hypertension is difficult given that patients are regularly managed with anticoagulation [23], and accurate animal models have proved challenging to develop [24]. Current areas of investigation include coagulation pathway abnormalities [25] and pulmonary vascular/endothelial factors [26]. For example, hereditary dysfibrinogenemia and polymorphism of the fibrinogen alpha gene, which likely lead to abnormal fibrin structure and resistance to endogenous thrombolysis $[28,29]$, appear to occur with higher prevalence in patients with chronic thromboembolic pulmonary hypertension than in the general population [30]. In addition, evidence suggests that multipotent growth potential of cells derived from ex vivo tissue from patients with chronic thromboembolic pulmonary hypertension may contribute to thrombus and vascular wall remodeling [31].

Limitations of our series include a lack of clinical information regarding type and duration of anticoagulation as well as time of surgery with respect to initial presentation. The referral nature of this surgical patient population, together with the retrospective nature of this study, preclude the accurate obtainment of these data. Future studies examining correlations with thrombus histology/age and duration and type of anticoagulation are warranted.

\section{Conclusions}

In summary, these results suggest that vascular remodeling, likely including in situ thrombosis, may be a critical hemodynamic factor in chronic thromboembolic pulmonary hypertension. Additional studies are needed to further characterize the factors that lead to nonresolution of pulmonary emboli and the local propagation of thrombi.

\section{Acknowledgements}

We thank Dr. Amara Majeed, former Cardiac Registry Fellow at Boston Children's Hospital, for helpful discussions. This research did not receive any specific grant from funding agencies in the public, commercial, or not-for-profit sectors.

\section{References}

1. Kim NH, Delcroix M, Jenkins DP, Channick R, Dartevelle P, et al. (2013) Chronic thromboembolic pulmonary hypertension. J Am Coll Cardiol 62: D92-D99. [Crossref]

2. Simonneau G, Robbins IM, Beghetti M, Channick RN, Delcroix M, et al. (2013) Updated clinical classification of pulmonary hypertension. J Am Coll Cardiol 62: D34D41. [Crossref]

3. Pengo V, Lensing AW, Prins MH, Marchiori A, Davidson BL, et al. (2004) Incidence of chronic thromboembolic pulmonary hypertension after pulmonary embolism. N Engl J Med 350: 2257-2264. [Crossref]

4. Becattini C, Agnelli G, Pesavento R, Silingardi M, Poggio R, et al. (2006) Incidence of chronic thromboembolic pulmonary hypertension after a first episode of pulmonary embolism. Chest 130: 172-175. [Crossref]

5. Lang IM, Pesavento R, Bonderman D, Yuan JX (2013) Risk factors and basic mechanisms of chronic thromboembolic pulmonary hypertension: a current understanding. Eur Respir J 41: 462-468. [Crossref]

6. Blauwet LA, Edwards WD, Tazelaar HD, McGregor CG (2003) Surgical pathology of pulmonary thromboendarterectomy: a study of 54 cases from 1990 to 2001. Hum Pathol 34: 1290-1298. [Crossref]
7. Bernard J, Yi ES (2007) Pulmonary thromboendarterectomy: a clinicopathologic study of 200 consecutive pulmonary thromboendarterectomy cases in one institution. Hum Patho 38: 871-877. [Crossref]

8. Mayer E, Jenkins D, Lindner J, D’Armini A, Kloek J, et al. (2011) Surgical management and outcome of patients with chronic thromboembolic pulmonary hypertension: results from an international prospective registry. J Thorac Cardiovasc Surg 141: 702-710. [Crossref]

9. Canadian Agency for Drugs and Technologies in Health (2014) Drug Therapy for Chronic Thromboembolic Pulmonary Hypertension: A Review of the Comparative Clinical Effectiveness. CADTH Rapid Response Reports.

10. Freed DH, Thomson BM, Tsui, SS, Dunning JJ, Sheares KK, et al. (2008) Functional and haemodynamic outcome 1 year after pulmonary thromboendarterectomy. Eur $J$ Cardiothorac Surg 34: 525-529.

11. Madani MM, Auger WR, Pretorius V, Sakakibara N, Kerr KM, et al. (2012) Pulmonary endarterectomy: recent changes in a single institution's experience of more than 2,700 patients. Ann Thorac Surg 94: 97-103. [Crossref]

12. Orfanos SE, Hirsch AM, Giovinazzo M, Armaganidis A, Catravas JD, et al. (2008) Pulmonary capillary endothelial metabolic function in chronic thromboembolic pulmonary hypertension. J Thromb Haemost 6: 1275-1280. [Crossref]

13. Yao W1, Firth AL, Sacks RS, Ogawa A, Auger WR, et al. (2009) Identification of putative endothelial progenitor cells (CD34+CD133+Flk-1+) in endarterectomized tissue of patients with chronic thromboembolic pulmonary hypertension. Am J Physiol Lung Cell Mol Physiol 296: 870-878. [Crossref]

14. Maruoka M, Sakao S, Kantake M, Tanabe N, Kasahara Y, et al. (2012) Characterization of myofibroblasts in chronic thromboembolic pulmonary hypertension. Int J Cardiol 159: 119-127. [Crossref]

15. Firth AL, Yao W, Ogawa A, Madani MM, Lin GY, et al. (2010) Multipoten mesenchymal progenitor cells are present in endarterectomized tissues from patients with chronic thromboembolic pulmonary hypertension. Am J Physiol Cell Physiol 298: 1217-12125. [Crossref]

16. Wang L, Guo LJ, Liu J, Wang W, Yuan XJJ, et al. (2013) MicroRNA expression profile of pulmonary artery smooth muscle cells and the effect of let-7d in chronic thromboembolic pulmonary hypertension. Pulm Circ 3: 654-664. [Crossref]

17. Wang L, Gan HL, Liu Y, Gu S, Li J, et al. (2013) The distinguishing cellular features of pulmonary artery smooth muscle cells from chronic thromboembolic pulmonary hypertension patients. Exp Lung Res 39: 349-358.

18. Sakao S, Tatsumi K (2013) Crosstalk between endothelial cell and thrombus in chronic thromboembolic pulmonary hypertension: perspective. Histol Histopathol 28: 185-193. [Crossref]

19. Sahasrabudhe N, Gosney JR, Hasleton P (2013) Chapter 1 - The normal lung: histology, embryology, development, aging and function. In: Spencer's Pathology of the Lung, Cambridge: Cambridge University Press, USA, Pp. 1-40.

20. Yi ES, Kim H, Ahn H, Strother J, Morris T, et al. (2000) Distribution of obstructive intimal lesions and their cellular phenotypes in chronic pulmonary hypertension: a morphometric and immunohistochemical study. Am J Respir Crit Care Med 162: 1577 1586. [Crossref]

21. Stary HC (2000) Natural history and histological classification of atherosclerotic lesions: an update. Arterioscler Thromb Vasc Biol 20: 1177-1178. [Crossref]

22. Rosenkrantz S (2015) Pulmonary hypertension 2015: current definitions, terminology, and novel treatment options. Clin Res Cardiol 104: 197-207. [Crossref]

23. Toshner M, Pepke-Zaba J (2014) Chronic thromboembolic pulmonary hypertension: time for research in pathophysiology to catch up with developments in treatment. F1000Prime Reports 38: 1-7. [Crossref]

24. Mercier O, Fadel E (2013) Chronic thromboembolic pulmonary hypertension: anima models. Eur Respir J 41: 1200-1206. [Crossref]

25. Bonderman D, Turecek PL, Jakowitsch J, Weltermann A, Adlbrecht C, et al. (2003) High prevalence of elevated clotting factor VIII in chronic thromboembolic pulmonary hypertension. Thromb Haemost 90: 372-376. [Crossref]

26. Kimura H, Okada O, Tanabe N, Tanaka Y, Terai M, et al. (2001) Plasma monocyte chemoattractant protein-1 and pulmonary vascular resistance in chronic thromboembolic pulmonary hypertension. Am J Respir Crit Care Med 164: 319-324. [Crossref]

27. Tsao TC, Xia W, Rodberg GM, Pinto CE, Kradin RL (1994) Interferon-gamma and tumor necrosis factor-alpha promote the binding of dendritic cells to fibronectin. Pathobiology 62: 120-126. [Crossref] 
28. Li JF, Lin Y, Yang YH, Gan HL, Liang Y, et al. (2013) Fibrinogen Aa Thr312Ala polymorphism specifically contributes to chronic thromboembolic pulmonary hypertension by increasing fibrin resistance. PLOS ONE 8: e69635. [Crossref]

29. Marsh JJ, Chiles PG, Liang NC, Morris TA (2013) Chronic thromboembolic pulmonary hypertension-associated dysfibrinogenemias exhibit disorganized fibrin structure. Thromb Res 132: 729-734. [Crossref]
30. Morris TA, Marsh JJ, Chiles PG, Magaña MM, Liang NC, et al. (2009) High prevalence of dysfibrinogenemia among patients with chronic thromboembolic pulmonary hypertension. Blood 114: 1929-1936. [Crossref]

31. Firth AL, Yao W, Ogawa A, Madani MM, Lin GY, et al. (2010) Multipotent mesenchymal progenitor cells are present in endarterectomized tissues from patients with chronic thromboembolic pulmonary hypertension. Am Physiol J Cell Physiol 298: C1217-C1225.

Copyright: (C2017 Kovach AE. This is an open-access article distributed under the terms of the Creative Commons Attribution License, which permits unrestricted use, distribution, and reproduction in any medium, provided the original author and source are credited. 